\title{
Extracts of Codiaeum variegatum (L.) A. Juss is Cytotoxic on Human Leukemic, Breast and Prostate Cancer Cell Lines
}

\author{
Mathias Tawiah Anim ${ }^{1}$, Christopher Larbie ${ }^{1 *}$, Regina Appiah-Opong ${ }^{2}$, Isaac Tuffour ${ }^{2}$, Kofi Baffour-Awuah Owusu², \\ Abigail Aning ${ }^{2}$ \\ ${ }^{1}$ Department of Biochemistry and Biotechnology, KNUST, Kumasi, Ghana. \\ ${ }^{2}$ Department of Clinical Pathology, NMIMR, University of Ghana, Legon, Ghana.
}

\begin{tabular}{l} 
ARTICLE INFO \\
\hline Article history: \\
Received on: $26 / 05 / 2016$ \\
Revised on: 14/07/2016 \\
Accepted on: 12/08/2016 \\
Available online: $29 / 11 / 2016$ \\
\hline Key words: \\
Antiproliferative, Codiaeum \\
variegatum, apoptosis, \\
cytotoxicity, fractionation, \\
antioxidant.
\end{tabular}

\begin{abstract}
The high cost of treatment of cancer coupled with the emergence of drug resistance makes it imperative for new drug interventions to curb its occurrence. Hence, the objective of this research was to determine the phytochemical, total phenolic content, antioxidant and antiproliferative effect of Codiaeum variegatum crude extracts and fractions. The MTT cell viability and DPPH assays among others were used to determine the selected properties of the plants. The presence of general glycosides, tannins, alkaloids, flavonoids and sterols was observed in its stem bark and leaf. Triterpenoids were present in the leaf only while saponins were observed in the stem bark only. Strong antioxidant activities were observed in both stem bark and leaf with $\mathrm{EC}_{50}$ values of $0.053 \pm 0.004 \mathrm{mg} / \mathrm{mL}$ and $1.396 \pm 0.073 \mathrm{mg} / \mathrm{mL}$ respectively. Both crude extracts showed antiproliferative activity towards all cancer cell lines with the stem bark exhibiting the strongest cytotoxicity. However, both showed strong cytotoxicity towards normal cells as well. The mechanism of cell death was determined to be apoptosis. Further testing of fractions from the stem bark crude extract revealed an increase in cytotoxicity of its chloroform fraction against Jurkat cells with an IC50 of $44.71 \pm 0.44 \mu \mathrm{g} / \mathrm{mL}$. These results establish the antiproliferative nature of this plant.
\end{abstract}

\section{INTRODUCTION}

Cancer is a term used to describe a large group of diseases characterized by the uncontrolled proliferation and spread of abnormal cells (Hayflick, 1997). Its incidence and mortality has risen tremendously over the past decade causing the need for effective control measures (Ferlay et al., 2013). It is estimated that the number of new cases is expected to rise by about $70 \%$ over the next two decades (World Cancer Report, 2014). Recent statistics by the International Agency for Research on Cancer (IARC) indicates a changing trend in recorded incidence and mortality of which less developed countries now record the highest number of cases (Ferlay et al., 2013). More than $60 \%$ of the world's total annual new cases occur in Africa,

\footnotetext{
* Corresponding Author

Email: ekowlarbie@gmail.com
}

Asia and Central and South America, with these regions accounting for $70 \%$ of the world's cancer deaths (World Cancer Report, 2014). Though there are several treatment options available, each comes with a high price tag often coupled with adverse side effects. The recently evolving paradigm of drug resistance to chemotherapeutic agents is also posing a great barrier to reducing the incidence and mortality of cancer (Shervington and $\mathrm{Lu}, 2008)$. Hence there is the need to exploit other remedies with possibly less known adverse effects and from readily accessible sources like plants. Plants could serve as a major source of bioactive compounds with potential efficacy against cancers (Talalay and Fahey, 2001). Codiaeum variegatum L. belongs to the family Euphorbiaceae and it's native to India, Philippines, Sri Lanka, Thailand, Indonesia, Malaysia and some other Pacific Islands (Stamps and Osborne, 2003). It is a common perennial plant with over 200 varieties worldwide; each different from the other with respect to the pattern and shades of colour as well as the size and shape of it leaf (Figure 1). 
Aside from its main purpose in serving as an ornamental, the root decoction of $C$. variegatum is used to treat gastric ulcers. The leaves have antibacterial and antiamoebic properties and can be crushed and drunk to cure diarrhoea (Moundipa et al., 2005). In indigenous Malaysian medicine, the plant is used as an antiinfective and an anti-cancer agent (Ali et al., 1996). Research conducted by Hassan et al. (2013) exposed the cytotoxicity effect of $C$. variegatum cv. petra leaves on human caucasian breast adenocarcinoma (MCF7), hepatocellular carcinoma (HepG2), colon cell line (HCT116) and lung carcinoma cell line (A549) with activities ranging from $17.3 \%$ to $98 \%$.

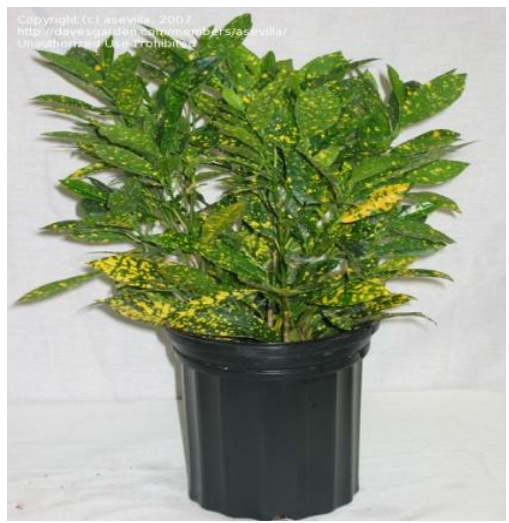

Fig. 1: Codiaeum variegatum cv Gold Dust.

The purpose of this research was to evaluate the cytotoxicity of $50 \%$ hydroethanolic extracts of $C$. variegatum $\mathrm{CV}$ gold dust on leukemia (Jurkat), breast (MCF 7) and prostate (PC 3) cancer cells. $C$. variegatum crude stem bark and leaf extracts were also analyzed for their phytochemical constituents, antioxidant activity, total phenolic content (TPC) and mode of cytotoxicity induction.

\section{MATERIAL AND METHODS}

\section{Cell lines and reagents}

The cell lines used (Jurkat, MCF 7, PC 3, WRL 68, HepG2) were obtained from RIKEN BioResource Centre Cell Bank (Japan). Culture media (RPMI and $\alpha$-MEM), 96 well plates, 3-(4,5-dimethylthiazol-2-yl)-2,5-diphenyltetrazolium bromide (MTT) dye, isopropanol, $\mathrm{HCl}$, trypan blue solution, absolute ethanol, foetal bovine serum (FBS), antibiotics (penicillin and streptomycin), 2, 2-diphenyl-1-picryl hydrazyl (DPPH), and phosphate buffer saline were obtained from Sigma-Aldrich Company (St. Louis, MO, USA).

\section{Plant material and extraction process}

Codiaeum variegatum cv. gold dust samples were handpicked from the environs of the New Times Corporation $\left(5^{\circ} 34^{\prime} 10.5^{\prime \prime} \mathrm{N} 0^{\circ} 13 ' 20.5^{\prime \prime} \mathrm{W}\right)$, North Industrial Area, Accra in April, 2014 before $9.00 \mathrm{am}$. Specimen of the plant was sent to the Department of Herbal Medicine, Faculty of Pharmacy and Pharmaceutical Sciences, KNUST, Kumasi for authentication by a taxonomist and a voucher specimen was deposited at the Herbarium for reference purpose (KNUST/HMI/2014/L094). The plant was sorted into stem bark and leaves. The stem bark component was chopped into pieces and both parts were washed separately with water three times and air dried at room temperature for three weeks. The dried samples were separately pulverized and packaged in zip-locks for further use. Preparation of $50 \%$ hydroethanolic extraction of the plant leaves and stems were carried out separately, by suspending $50 \mathrm{~g}$ of the powder of each part in $500 \mathrm{~mL}$ of $50 \%$ ethanol $(50: 50 \mathrm{v} / \mathrm{v})$. The extraction was done by cold maceration for $24 \mathrm{hrs}$ at room temperature on a shaker. The extracts were filtered through cotton wool, concentrated using a rotary evaporator and freeze-dried to obtain the $C$. variegatum hydroethanolic leaf and stem bark crude extracts.

\section{Fractionation of $C$. variegatum stem bark hydroethanolic extract}

Fractionation of the hydroethanolic stem bark extract of C. variegatum was carried out in a separating funnel using solvents of increasing polarity, petroleum ether, chloroform and ethyl acetate. A mass of $1.5 \mathrm{~g}$ was dissolved in $15 \mathrm{~mL}$ of $50 \%$ ethanolic solution and was successively partitioned with petroleum ether, then chloroform and finally with ethyl acetate, each having a volume of $30 \mathrm{~mL}$, to obtain petroleum ether, chloroform and ethyl acetate fractions. This was done for two to three times as polarity increased. The remaining portion was designated as hydroethanolic fraction.

\section{Phytochemical screening}

The phytochemicals tested for were general glycosides, anthracene glycosides, saponins, tannins, alkaloids, flavonoids, sterols and triterpenoids. The presence of these phytochemicals in the crude extracts was analyzed using standard methods (Trease and Evans, 1989; Sofowora, 1993; Harborne, 1998).

\section{Determination of total phenols}

Total phenolic content (TPC) of leaf and stem bark was determined using the Folin-Ciocalteau assay with slight modification (Marinova et al., 2005). To a volume of $10 \mu \mathrm{L}$ of sample, $790 \mu \mathrm{L}$ of distilled water was added. The concentration of the leaf and stem bark extracts tested was $5 \mathrm{mg} / \mathrm{mL}$. A volume of $50 \mu \mathrm{L}$ of Folin-Ciocalteau reagent was added to the diluted samples and thoroughly mixed. The mixtures were incubated in the dark for 8 mins. Subsequently, $150 \mu \mathrm{L}$ of $7 \% \mathrm{Na}_{2} \mathrm{CO}_{3}$ was added before incubation of the mixture for $2 \mathrm{hrs}$ in the dark at room temperature. Triplicate experiments were performed. The absorbance was read at a wavelength of $750 \mathrm{~nm}$ using a microplate reader (Tecan Infinite M200, Austria). Gallic acid (GA) was used as the standard phenolic compound. A GA calibration curve was plotted and used to determine the total phenolic content. The results were expressed in milligrams of GA equivalents per gram dry mass (mg GAE/g DM). 


\section{Determination of antioxidant activity}

The antioxidant activity of $C$. variegatum leaf and stem bark extracts was determined using the free radical scavenging activity by DPPH method with some modification (Blois, 1958). Methanolic solution of DPPH $(0.5 \mathrm{mM})$ was added to equal volumes of various concentrations of each extract (concentration range $0-5 \mathrm{mg} / \mathrm{mL}$ ). After 20 mins incubation at room temperature, the absorbance was read at a wavelength of $517 \mathrm{~nm}$ (Tecan Infinite M200 Pro plate reader, Austria). The inhibition concentration at $50 \%\left(\mathrm{IC}_{50}\right)$ value of each extract was calculated from the following formula:

$$
\% \text { Antioxidant activity }=\left[\left(\mathrm{A}_{0}-\mathrm{A}_{1}\right) / \mathrm{A}_{0} \times 100\right]
$$

Where $A_{0}$ is the absorbance of negative control (methanol), and $A_{1}$ is the absorbance of test sample with DPPH. Butylated hydroxytoluene (BHT) was used as standard control. Triplicate experiments were performed. The half maximal effective concentration $\left(\mathrm{EC}_{50}\right)$ value, which is the concentration of the extracts that can cause $50 \%$ free radical scavenging activity, was determined.

\section{MTT assay}

L-RPMI and $\alpha$-MEM culture media, respectively, supplemented with $10 \%$ foetal bovine serum (FBS), containing penicillin, streptomycin, and L-glutamine were maintained in culture at $37^{\circ} \mathrm{C}$ in a humidified $5 \% \quad \mathrm{CO}_{2}$ atmosphere. The tetrazolium-based colorimetric assay (MTT) was used to determine the cytotoxicity of $C$. variegatum on the cancer and normal cell lines (Ayisi et al., 2011). Triplicate experiments were performed. Cells were seeded into the 96-well plates at the concentration of $1 \times 10^{4}$ cells/well, treated with varying concentrations of the plant extracts $(0-1000 \mu \mathrm{g} / \mathrm{mL})$ and incubated as indicated above for $72 \mathrm{hrs}$. A color control plate was also setup for each extract including the positive control, curcumin. MTT solution $(0.5 \mathrm{mg} / \mathrm{mL})$ was added to each well on the plate, and incubation continued for further $4 \mathrm{hrs}$. The reaction was stopped with acidified isopropanol solution, and the plate incubated in the darkness overnight at room temperature before reading the absorbance at $570 \mathrm{~nm}$ using a microplate reader (Tecan Infinite M200 Pro, Austria). The percentage cell viability was determined as follows:

$\%$ Cell Viability $=(($ Absorbance of treated cells - Absorbance of blank $) /$ (Absorbance of untreated cells - Absorbance of blank))x100

The $\mathrm{IC}_{50}$ values were determined from the plot of percent cell viability on the $\mathrm{y}$-axis against extract concentrations on the $\mathrm{x}$-axis.

\section{Nuclear morphology examination (Hoechst staining)}

MCF-7 cells were seeded at $1 \times 10^{6}$ cells $/ \mathrm{mL}$ in a total volume of $6 \mathrm{~mL}$ in sterile petri dishes and incubated for $24 \mathrm{hrs}$ at $37{ }^{\circ} \mathrm{C}$ in $5 \% \mathrm{CO}_{2}$ to allow the cells to adhere to the dishes. The cells were then treated with two different concentrations (20 and $40 \mu \mathrm{g} / \mathrm{mL}$ ) of the most active crude extract (C. variegatum stem bark) and standard urosolic acid $(5.7 \mu \mathrm{g} / \mathrm{mL})$ and then re-incubated for $24 \mathrm{hrs}$ at $37{ }^{\circ} \mathrm{C}$ in $5 \% \mathrm{CO}_{2}$. The cells were scraped from the petri dishes with a cell lifter and transferred into $15 \mathrm{~mL}$ centrifuge tubes. Centrifugation was done at $1000 \mathrm{rpm}$ for $5 \mathrm{~min}$ and the supernatant was discarded. The remaining cell pellets were resuspended in $1 \mathrm{~mL}$ of phosphate buffered saline (PBS). The cells were then transferred into $1.5 \mathrm{~mL}$ eppendorf tubes and centrifuged at $1000 \mathrm{rpm}$ for $5 \mathrm{~min}$. The supernatant was discarded and the cell pellets were treated with $200 \mu \mathrm{L}$ of $1 \%$ glutaraldehyde and then incubated at room temperature for $30 \mathrm{~min}$. The centrifugation was subsequently repeated (as above) and the supernatant was removed. A volume of $50 \mu \mathrm{L}$ of PBS and $8 \mu \mathrm{L}$ of Hoechst solutions was finally added and mixed gently but uniformly. The samples were applied on microscope slides, covered with cover slips, mounted and examined on a fluorescent microscope (Olympus, U.S.A).

\section{Flow-cytometry analysis}

MCF-7 cells were seeded at $2 \times 10^{5}$ cells $/ \mathrm{mL}$ in a total volume of $3 \mathrm{~mL}$ in sterile petri dishes and incubated for $24 \mathrm{hrs}$ at $37{ }^{\circ} \mathrm{C}$ in $5 \% \mathrm{CO}_{2}$. The cells were then treated with different concentrations ( 20 and $40 \mu \mathrm{g} / \mathrm{mL}$ ) of the most active crude extract (C. variegatum stem bark) and standard curcumin and then reincubated for $24 \mathrm{hrs}$ at $37^{\circ} \mathrm{C}$ in $5 \% \mathrm{CO}_{2}$. The cells were scraped from the petri dishes with a cell lifter and stirred gently and uniformly. A volume of $100 \mu \mathrm{L}$ was aliquoted into wells in a 96 well plate. An equal volume of the Guava Nexin Reagent was aliquoted into each well, mixed thoroughly and incubated for 20 mins. The plates were read in a flow cytometer (Guava Easycyte, Germany) (Vermes et al., 1995).

\section{Statistical analysis}

Data were analyzed by one-way analysis of variance and the means assessed by Tukey's test at 5\% level of significance ( $p$ $<0.05)$ using Graph pad Prism version 5.0. The results were expressed as mean $\pm \mathrm{SD}$.

\section{RESULTS AND DISCUSSION}

\section{Phytochemical screening}

Medicinal plants are of great importance to the general health of individuals and communities. It is also an immense source of medicines in pharmacognosy. Research by Ogunwenmo et al. (2007) proved a difference in the phytochemical constituents among various $C$. variegatum varieties. The presence of alkaloids, saponins, and tannins were reported by Ogunwenmo et al. (2007) to be varying in levels among varieties of this plant. With respect to the $C$. variegatum cv gold dust tested in this research, both its stem bark and leaf tested positive for general glycosides, tannins, alkaloids, flavonoids and sterols as shown in table 1. However, saponins were absent from the crude extract of $C$. variegatum leaves, (probably due to the difference in variety as compared to that used by Ogunwenmo et al., 2007) while its stem bark showed no traces of triterpenoids. The presence of alkaloids, saponins, tannins in such high concentrations could render this plant, 
antibacterial and antiamoebic and this could be related to its use in the treatment of diarrhoea (Moundipa et al., 2005).

Table 1: The phytochemical constituents present in hydroethanolic extracts of C. variegatum.

\begin{tabular}{|c|c|c|}
\hline Phytochemical & Stem bark & Leaf \\
\hline General glycoside & ++ & ++ \\
\hline Anthracene glycoside & - & - \\
\hline Saponins & +++ & - \\
\hline Tannins & +++ & +++ \\
\hline Alkaloids & ++ & +++ \\
\hline Flavonoids & +++ & +++ \\
\hline Sterols & +++ & +++ \\
\hline Triterpenoids & - & +++ \\
\hline
\end{tabular}

\section{Total phenol content}

The total phenolic content was extrapolated from the standard calibration curve $\left(y=0.392 x+0.036, R^{2}=0.991\right)$ obtained from GA. Figure 2 shows the levels of TPC in the leaf and stem bark extracts. The TPC of the stem bark extract was significantly higher $(p=0.0005)$ as compared to the leaf extract as shown in Figure 2.

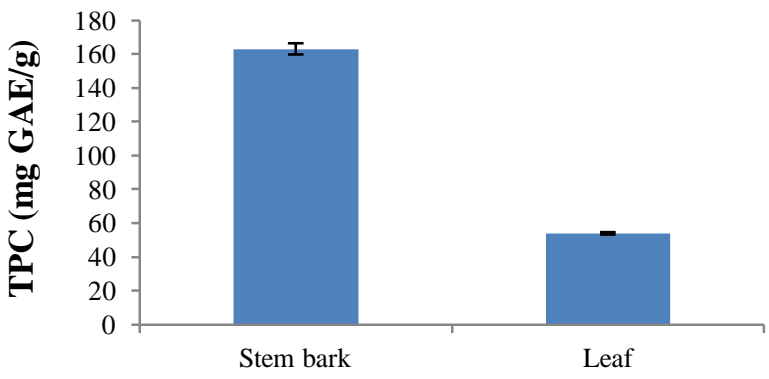

Plant extracts

Fig. 2: Total phenolic content of hydroethanolic extracts of $C$. variegatum stem bark and leaf expressed as mean \pm standard deviation $(p=0.0005)$.

\section{Antioxidant activity}

Figure 3 shows the antioxidant activity of $C$. variegatum stem bark and leaf extracts. Both extracts and standard BHT exhibited strong antioxidant activity in a dose dependent manner. All the samples analysed showed an increase in antioxidant activity with increasing concentrations, thus exhibiting a concentration dependent pattern of free radical scavenging ability. The stem bark extract of $C$. variegatum recorded the strongest antioxidant activity. The stem bark of the $C$. variegatum appeared to have stronger antioxidant activity as compared with the standard (BHT) $(p<0.0001)$. Members of the Euphorbiaceae plant family possess strong antioxidant activities which are greatly associated with the presence of phenolic compounds (Shahwar et al., 2010). For instance, analysis of the leaf extract of $C$. variegatum cv spiral and royal-like by HPLC-DAD showed that ellagic acid, a phenolic compound may be responsible for its antioxidant activity (Saffoon et al., 2014). Findings from this research proved that the stem bark of the $C$. variegatum recorded the highest concentration of total phenolics for this plant, suggesting that the observed antioxidant activity could be partly attributed to the high levels of total phenolics present in the sample. (Figure 3)
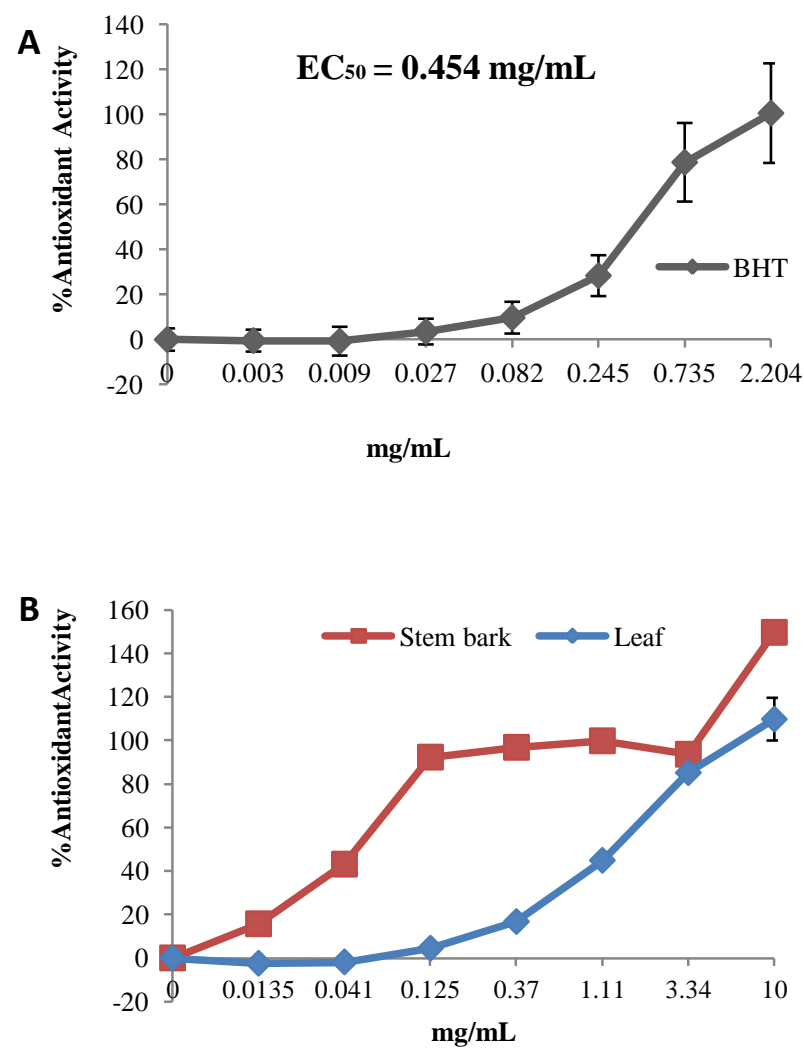

Fig. 3: Antioxidant activity of (A) BHT, (B) C. variegatum stem bark and $C$. variegatum leaf. Each point represents three determinations.

\section{Antiproliferative activity of extracts and curcumin}

Table 2 shows the antiproliferative effect of the extracts and standard (curcumin) on Jurkat cells, MCF 7, PC 3 and WRL 68 cell lines. The stem bark extract showed stronger inhibitory effect on all the cell lines compared to the leaf extract. All the extracts and curcumin inhibited the growth of the normal cell WRL 68, indicating a poor selectivity (Table 2).

A previous study on $C$. variegatum cv petra established the cytotoxicity of the leaves of this plant on human caucasian breast adenocarcinoma (MCF7), hepatocellular carcinoma (HepG2), colon cell line (HCT116) and lung carcinoma cell line (A549) with activities ranging from $17.3 \%$ to $98 \%$ (Hassan et al., 2013). This was confirmed in this research since both parts of the plant showed various levels of cytotoxicity against MCF 7 cells, with the stem bark of $C$. variegatum being the most cytotoxic part with an $\mathrm{IC}_{50}$ of $35.55 \pm 1.50 \mu \mathrm{g} / \mathrm{mL}$. A similar trend was observed with respect to leukaemia (Jurkat) and prostate (PC 3) cancer cell lines where the stem bark recorded an $\mathrm{IC}_{50}$ of $59.71 \pm 12.20$ 
$\mu \mathrm{g} / \mathrm{mL}$ and $52.54 \pm 1.88 \mu \mathrm{g} / \mathrm{mL}$ as compared to $62.03 \pm 8.49$ $\mu \mathrm{g} / \mathrm{mL}$ and $211.20 \pm 77.09 \mu \mathrm{g} / \mathrm{mL}$ recorded by its leaf. This suggests that the stem bark of $C$. variegatum could possibly be a better source of bioactive compounds for chemotherapy than its leaf. In elucidating the cytotoxic effect on the normal human liver cell line (WRL 68), it was observed that the stem bark of $C$. variegatum was the most toxic part. None of the extracts showed good selectivity against the cancer cell lines with respect to the normal human liver cells. This suggests that even the most active part of the plant could in one way or the other cause damage to the liver and probably other organs of the body when this medicine is administered. However, further studies will be needed to eliminate the toxic components of the extracts and isolate the active principle.

Table 2: Cytotoxic activities of $C$. variegatum crude extracts.

\begin{tabular}{lllll}
\hline \multicolumn{5}{c}{ IC $_{\mathbf{5 0}}$ values $(\boldsymbol{\mu g} / \mathbf{m L})$} \\
\hline Cell Line & Stem bark & Leaf & Curcumin & $\boldsymbol{p}$-value \\
\hline Jurkat & $59.71 \pm 12.20$ & $62.03 \pm 8.49$ & $1.84 \pm 0.16$ & 0.0002 \\
MCF 7 & $35.55 \pm 1.50$ & $84.44 \pm 1.53$ & $3.65 \pm 0.08$ & $<0.0001$ \\
PC 3 & $52.54 \pm 1.88$ & $211.20 \pm 77.09$ & $8.10 \pm 0.82$ & 0.0032 \\
WRL 68 & $49.37 \pm 2.7$ & $74.55 \pm 4.8$ & $8.35 \pm 0.40$ & $<0.0001$ \\
\hline
\end{tabular}

Tabulated values represent mean \pm standard deviation of three replicates. $p$-values compare the statistical difference between the calculated means using Tukey's test. For each plant extract tested $n=3$

\section{Nuclear morphology examination (Hoechst staining)}

Apoptosis is often characterised by nuclear condensation, chromosomal DNA fragmentation and the formation of cell fragments called apoptotic bodies (Bruce et al., 2008). Cells that are not undergoing cell death often possess a nucleus with the normal, roughly spherical morphology. The most active crude extract among all the extracts tested, $C$. variegatum stem bark, was analysed to elucidate its molecular mechanism of action. The effect of this selected crude extract on the nuclear morphology of breast cancer cells (MCF 7) and its specific mode of action was analysed using the Hoechst staining. The presence of fragmented or shrunk nuclei was observed in $C$. variegatum stem bark treated cells as well as standard urosolic acid. Figure 4 shows the effect of C. variegatum stem bark extract on MCF 7 cells.

Hoechst staining showed that there were significant morphological changes in nuclear chromatin similar to the changes observed in the apoptotic mechanism of action by other members of the Euphorbiaceae family on MCF 7 cells (Aslanturk and Celik, 2013).

\section{Flow cytometry analysis}

Figure 5 shows the mechanism of action of $C$. variegatum stem bark on MCF 7 cells. The extract induced cytotoxicity in a dose dependent manner and the mode of cytotoxicity was confirmed to be apoptosis. (Figure 5)

Data generated from the flow cytometry assay indicated and confirmed a dose-dependent and apoptotic mode of cytotoxicity for $C$. variegatum stem bark at 20 and $40 \mu \mathrm{g} / \mathrm{mL}$. Emerging evidence has demonstrated that, the anticancer activities of certain chemotherapeutic agents involved in the induction of apoptosis have no side effects on normal tissues, and are thus regarded as the preferred method of treating cancer (Xiao, 2007). Hence, the apoptotic nature of $C$. variegatum renders it a good candidate for chemoptherapy.
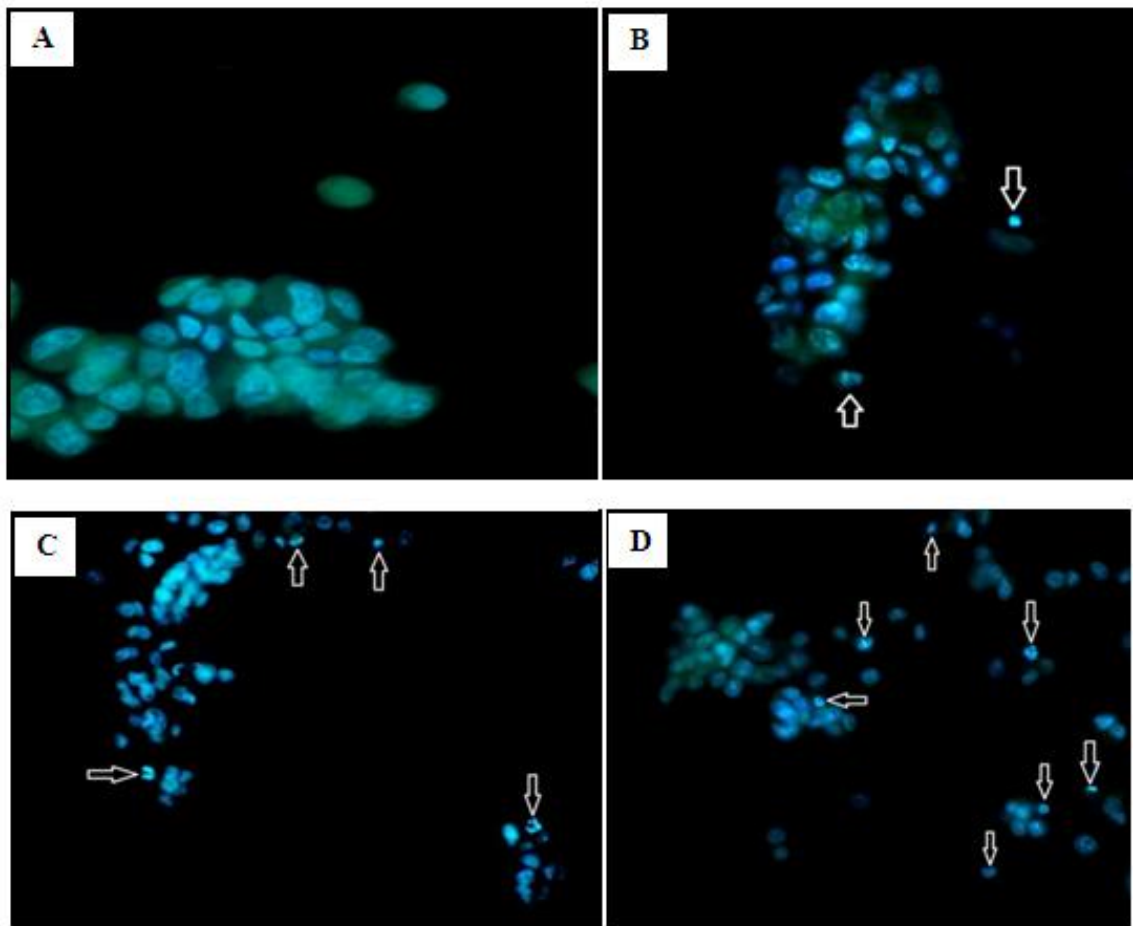

Fig. 4: Nuclear morphology of MCF 7 cells after 24 hrs of incubation without any treatment, control (A), treatment with $20 \mu \mathrm{g} / \mathrm{mL}$ (B), $40 \mu \mathrm{g} / \mathrm{mL}$ of $C$. variegatum stem bark extract (C) and urosolic acid (standard) (D). Arrows point to nuclei that are fragmented/shrunk 

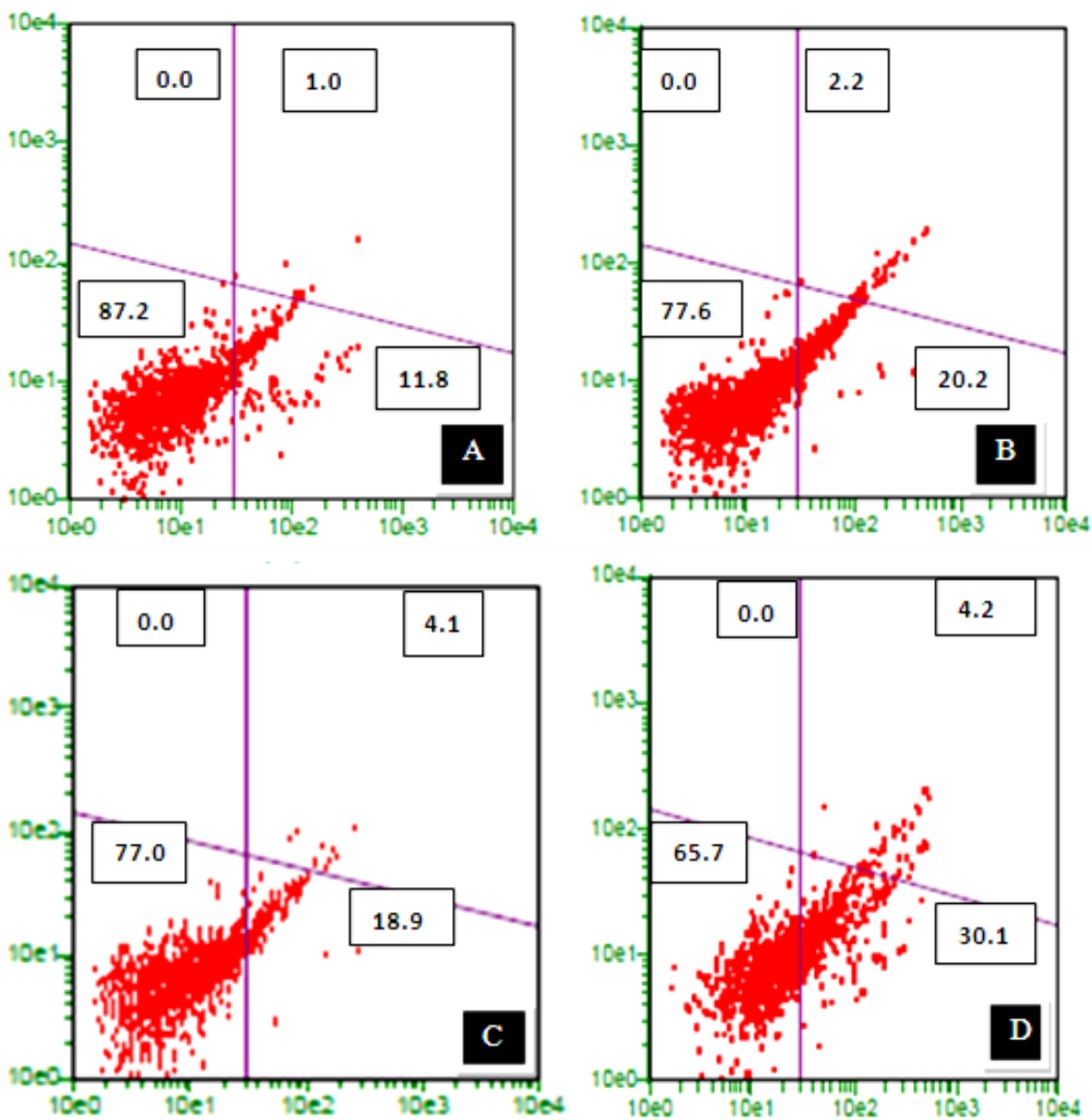

Fig. 5: Flow cytometry evaluation of apoptotic effects on MCF 7 cells after $24 \mathrm{hrs}$ of incubation without any treatment, control (A) and treatment with $20 \mu \mathrm{g} / \mathrm{mL}$ (B), $40 \mu \mathrm{g} / \mathrm{mL}$ (C) of C. variegatum stem bark extract and curcumin (standard) (D). Inserted values represent percentage of cells of two replicates., Upper left quadrant represents nuclear debris, upper right quadrant represents cells in late apoptotic stage, lower left quadrant represents non apoptotic cells and lower right quadrant represents cells in early stage apoptosis.

Table 3: Cytotoxic activities of fractions of C. variegatum stem bark

\begin{tabular}{lccccc}
\hline \multirow{2}{*}{ Cell Line } & \multicolumn{5}{c}{ IC $_{\mathbf{5 0}}$ values $(\boldsymbol{\mu g} / \mathbf{m L})$} \\
\cline { 2 - 6 } & Pet-ether fr. & Chloroform fr. & Ethyl acetate fr. & Hydroethanol fr. & Curcumin \\
\hline Jurkat & $80.87 \pm 13.90$ & $44.71 \pm 0.44$ & $560.27 \pm 22.16$ & $498.17 \pm 4.74$ & $1.90 \pm 0.16$ \\
MCF 7 & $736.56 \pm 183.7$ & $675.80 \pm 33.06$ & $>1000$ & $>1000$ & $<0.0001$ \\
HepG2 & $>1000$ & $>1000$ & $>1000$ & $>1000$ & $2.93 \pm 0.62$ \\
\hline
\end{tabular}

Tabulated values represent mean \pm standard deviation of three replicates $p$-values compare the statistical difference between the calculated means using Tukey's test. For each fraction $n=3$

\section{Antiproliferative activity of stem bark fractions and curcumin}

The antiproliferative activity of petroleum ether, chloroform, ethyl acetate and hydroethanolic fractions against Jurkat, MCF 7 and HepG2 was assessed. (Table 3).

Fractionation of the stem bark extract was performed to verify if the fractions could elicit an increase in cytotoxic activity. The fractions were tested against MCF 7, Jurkat and HepG2 cell lines. With the exception of the chloroform extract of $C$. variegatum stem bark which recorded an increase in cytotoxicity towards Jurkat cells, with an $\mathrm{IC}_{50}$ of $44.71 \pm 0.44 \mu \mathrm{g} / \mathrm{mL}$ compared to the extract; all the other fractions were relatively less toxic against the cancer cells as compared to the crude extract. This could be attributed to the fact that the active molecules in the extract worked in a synergistic manner (or the activity of the active compound was complemented by another compound) and individually was not that effective. On the other hand, it is possible that the solvents used for fractionation were unsuitable for the purpose.

\section{CONCLUSION}

This study provides information on the phytochemical constituents, antioxidant and antiproliferative effect of $C$. variegatum. From the study the stem bark of $C$. variegatum exhibited a stronger free radical scavenging activity than its leaf, though both had good antioxidant properties. However, further 
study on the stem bark of $C$. variegatum is needed to reveal its active principle.

Findings from this study indicates that $C$. variegatum has antiproliferative effect on leukaemia (Jurkat), breast (MCF 7) and prostate (PC 3) cancer cell lines and possibly contain bioactive compounds with anticancer properties.

However, though the stem bark and leaf of $C$. variegatum showed interesting anticancer activities both were very toxic to the normal human liver cells (WRL 68), suggesting a possible health risk to individuals who take the preparations of this extract for the purpose of alleviating illnesses especially on chronic users. However, it is imperative that this research is repeated in animal models such as mice. This will help serve as an index of its potential toxicity in humans.

Also, further fractionation of the stem bark revealed an increase in cytotoxicity of its chloroform fraction towards Jurkat relative to the crude extract, indicating the presence of some bioactive compound(s) in this fraction.

In addition to the anticancer evaluation, the molecular studies conducted on the $C$. variegatum stem bark crude extract using the Hoechst staining and flow cytometry revealed an apoptotic mechanism of action. This renders it a great candidate with promising leads to medicines against cancer.

\section{ACKNOWLEDGEMENT}

The Molecular Biology Laboratory of the Department of Biochemistry and Biotechnology, Department of Pharmacognosy, Kwame Nkrumah University of Science and Technology and the Clinical Pathology Department of Noguchi Memorial Institute for Medical Research, University of Ghana supported this research.

Conflict of Interests: There are no conflicts of interest.

\section{REFERENCES}

Ali AM, Mackeen MM, El-Sharkawy SH, Hamid J, Ismail NH, Ahmed BF, Lajis N. Antiviral and cytotoxic activities of some plants used in Malaysian Indigenous Medicine. Pertanika Journal of Tropical Agricultural Science. 1996; 19(2/3): 129-36.

Aslanturk OS, Celik TA. Antioxidant, cytotoxic and apoptotic activities of extracts from medicinal plant Euphorbia platyphyllos L. Journal of Medicinal Plants Research. 2013; 7(19): 1293-304.

Ayisi NK, Appiah-Opong R, Gyan B, Bugyei K, Ekuban F. Plasmodium falciparum: assessment of selectivity of action of chloroquine, Alchornea cordifolia, Ficus polita, and other drugs by a tetrazolium-based colorimetric assay. Malaria Research and Treatment. $2011 ; 816250$.

Blois MS. Antioxidant determinations by the use of a stable free radical. Nature. 1958; 181:1199-200.

Bruce A, Alexander J, Julian L, Martin R, Keith R, Walter P. Apoptosis: Programmed cell death eliminates unwanted cells. $5^{\text {th }}$ ed. New York: Garland Science; 2008.

Ferlay J, Soerjomataram I, Ervik M, Dikshit R, Eser S, Mathers C, Rebelo M, Parkin DM, Forman D, Bray F. GLOBOCAN 2012 v1.0, Cancer Incidence and Mortality Worldwide: IARC Cancer Base No. 11. Lyon: International Agency for Research on Cancer Press; 2013.
Ghasemi K, Ghasemi Y, Ebrahimzadeh MA. Antioxidant activity, phenol and flavonoid contents of 13 citrus species peels and tissues. Pakistan Journal of Pharmaceutical Sciences. 2009; 22(3): 277-81.

Hassan EM, Hassan RA, Sakib JY, Mohamed SM, El-Toumy SA. Chemical constituents and cytotoxic activity of Codiaeum variegatum CV. petra. Journal of Applied Sciences Research. 2013; 9(8).

Harborne JB. Phytochemical methods: A guide to modern techniques of plant analysis. $3^{\text {rd }}$ ed. London: Chapman and Hall; 1998.

Hayflick L. Mortality and immortality at the cellular level: A review. Biochemistry. 1997; 62:1180-190.

Marinova D, Ribarova F, Atanassova M. Total phenolics and total flavonoids in Bulgarian fruits and vegetables. Journal of the University of Chemical Technology and Metallurgy. 2005; 40(3):255-60.

Moundipa P, Kamini G, Charles F, Iris B. Medicinal Plants from Cameroon with amoebicidal activity: Codiaeum variegatum, a potential source of new products against Amoebiasis. African Journal of Traditional, Complementary and Alternative Medicine. 2005; 2: 113-21.

Ogunwenmo O, Idowu O, Innocent C, Esan B, Oyelana A. Cultivars of Codiaeum variegatum (L.) Blume (Euphorbiaceae) show variability in phytochemical and cytological characteristics. African Journal of Biotechnology. 2007; 6(20): 2400-5.

Saffoon N, Uddin R, Subhan N, Hossain H, Reza M, Alam A. In vitro anti-oxidant activity and HPLC-DAD system based phenolic content analysis of Codiaeum variegatum found in Bangladesh. Advanced Pharmaceutical Bulletin. 2014; 4(2): 533-41.

Shahwar D, Rehman S, Ahmad N, Ullah S, Raza M. Antioxidant activities of the selected plants from the family Euphorbiaceae, Lauraceae, Malvaceae and Balsaminaceae. African Journal of Biotechnology. 2010; 9(7): 1086-96.

Shervington A, Lu C. Expression of multidrug resistance genes in normal and cancer stem cells. Cancer Investigation. 2008; 26(5):535-42.

Sofowora A. Phytochemical screening of medicinal plants and traditional medicine in Africa. 2nd ed. Ibadan: Spectrum Books Limited; 1993.

Stamps RH, Osborne LS. Croton production and use. Circular ENH 878, Series of the Environmental Hort. Dept., COOP. Ext. services. Florida: IFAS Univ. Florida EIDS; 2003.

Talalay P, Fahey JW. Phytochemicals from cruciferous plants protect against cancer by modulating carcinogen metabolism. Journal of Nutrition. 2001; 131: 3027-33.

Trease GE, Evans WC. Pharmacognosy. $12^{\text {th }}$ ed. London: Balliere-Tindall; 1989.

Vermes I, Haanen C, Steffens-Nakken H, Reutelingsperger C. A novel assay for apoptosis. Flow cytometric detection of phosphatidylserine expression on early apoptotic cells using fluorescein labeled Annexin V. Journal of Immunological Methods. 1995; 184:39-51.

World Cancer Report (2014). International Agency for Research on Cancer, WHO Press.

Xiao JX, Huang GQ, Zhang SH. Soya saponins inhibit the proliferation of $\mathrm{HeLa}$ cells by inducing apoptosis. Experimental and Toxicologic Pathology. 2007; 59:35-42.

How to cite this article:

Anim MT, Larbie C, Opong RA, Tuffour I, Owusu KBA, Aning A. Extracts of Codiaeum variegatum (L.) A. Juss Is Cytotoxic on Human Leukemic, Breast and Prostate Cancer Cell Lines. J App Pharm Sci, 2016; 6 (11): 087-093. 